\title{
Hydrogel Nanoparticle as a Functional Coating Layer in Biosensing, Tissue Engineering, and Drug Delivery
}

\author{
Heejoo Cho ${ }^{1, *}$, Sumin Jeon ${ }^{2}$, Junghyeok Yang ${ }^{3}$, Song Yi Baek ${ }^{4}$ and Doeun Kim ${ }^{5}$ \\ 1 R\&D Center, Scholar Foxtrot Co., Ltd., Seoul 04626, Korea \\ 2 Concordia International School Shanghai, Shanghai 201206, China; esotericakr@naver.com \\ 3 Cornerstone Collegiate Academy of Seoul, Seoul 06779, Korea; joo1123kr@gmail.com \\ 4 Branksome Hall Asia, Seoqwipo 63644, Korea; unuti7942@scholarfoxtrot.com \\ 5 Phil-Mount Christian Academy, Erdenheim, PA 19038, USA; kim@scholarfoxtrot.com \\ * Correspondence: cho@scholarfoxtrot.com; Tel.: +82-2-2274-7260
}

Received: 4 June 2020; Accepted: 6 July 2020; Published: 10 July 2020

check for updates

\begin{abstract}
The development of functional coating materials has resulted in many breakthroughs in the discovery of energy, environmental, and biomedical applications. Responsive polymeric hydrogels are an example of smart coating materials due to their stimuli-responsive characteristics upon changes in their local environment. This review focuses on the introduction of hydrogel nanoparticles and their applications in functional layers as responsive coating materials. Hydrogels are explained by the composition of cross-links and monomers used for preparation. In particular, an important class of responsive hydrogels, that is, nanosized hydrogel particles (nanogels), are described for thee synthesis, modification, and application in assembly of functional coating layers. Finally, nanogel functional layers for biological applications will be discussed with recent advances in biosensing, tissue engineering, and drug delivery.
\end{abstract}

Keywords: responsive hydrogels; hydrogel nanoparticles; nanogels; smart coatings; biosensing layer

\section{Introduction}

Hydrogels have dual characteristics in the states of matter, making them complicated to define due to their fluidic and solid-like properties. For instance, hydrogels maintain the structural integrity of a solid when removed from their aqueous container. However, hydrogels enable the transport of small molecules through hydrogel networks thanks to their fluid-like properties. Thus, hydrogels could be defined as cross-linked polymeric materials swelling in an aqueous phase [1-4]. In this definition, hydrogels are considered as cross-linked networks with visco-elastic behavior, providing dimensional stability as a soft material. The swelling behavior of hydrogels is also important to characterize, which allows them to absorb thousand times their dry weight in aqueous media [4-6]. Such swelling properties are tunable by cross-links as well as by monomers. This enables them to act on many stimuli through the endothermic/entropy-driven phase transition [3]. The recent development of responsive hydrogels has advanced the property for novel applications in tunable optical elements [7-11], micro-fluidic flow control [12-17], surface patterning [18-20], sensing transducers [21-28], catalysis [29-32], drug delivery [33-52], protein separation [53-56], cellular/tissue engineering [5,57-63], and bio-assays/sensing [2,21,64-75]. Overall, this review aims to introduce hydrogels by composition and synthesis, followed by describing their responsivity and applications in functional coating layers for biosensing, tissue engineering, and drug delivery. 


\section{Composition and Synthesis of Hydrogels}

\subsection{Cross-Links in Hydrogels}

Cross-links play a key role in maintaining the structural stability of hydrogels as well as the entanglement of hydrophilic chains. Hydrogels are categorized into physically and chemically cross-linked hydrogels [3]. The networks of hydrogels with physical cross-links are coalesced by noncovalent interactions including hydrophobic interactions, ionic interactions, hydrogen bonds, and protein-ligand bonds [1,3,6,76-81]. Physically cross-linked hydrogels can develop reversibly degradable hydrogels, undergoing a transition from a dimensionally stable polymer to a polymer solution. Noncovalent interactions among hydrogel networks, which are relatively weaker than covalent interactions, facilitate their transition behavior between entangled and dissolved states. These hydrogels are favorable for encapsulating proteins, drugs, or cells and then releasing them from the dissolved hydrogels $[33,59,82,83]$.

For hydrogels with chemical cross-links, their networks are covalently formed by polymerizing monomers with cross-linking agents such as $N, N^{\prime}$-methylene(bisacrylamide) (BIS), providing stronger hydrogel structures than those of physical cross-links [1,3,15]. In this approach, hydrogel properties are also tunable by incorporating diverse functional moieties into the hydrogel backbone network, which allows for the formation of responsive hydrogels responding to various stimuli. For instance, functional moieties could be like those of peptides and small molecules.

\subsection{Monomers in Hydrogels}

Hydrogels are polymeric materials prepared by the polymerization of monomers and/or cross-linking agents in the presence (or absence) of a surfactant. Thus, the physiochemical properties of the polymeric hydrogels are mainly determined by the monomers used for the polymerization. Based on the type of the monomers used, the hydrogels are enabled to undergo a phase transition in response to external stimuli such as temperature, $\mathrm{pH}$, photon flux, ionic strength, and electric currents [7,10,84-102]. N-Isopropylacrylamide (NIPAm) is an extensively used monomer for hydrogel formation due to its temperature-dependent behavior in aqueous solutions, which results in the formation of thermoresponsive poly $(\mathrm{N}$-isopropylacrylamide) $\mathrm{pNIPAm}$ hydrogel via a number of polymerization methods [92,96,103-109]. Such hydrogels undergo a reversible phase transition at the lower critical solution temperature (LCST) or upper critical solution temperature (UCST) of the polymer as the hydrogel goes from a swollen state to a deswollen state, or vice versa $[84,86,96,110,111]$. By adding another monomer (i.e., acrylic acid (AAc)) during the polymerization process, the thermoresponsive hydrogels can be equipped with $\mathrm{pH}$ responsivity, which allows for the formation of the thermo/pH-responsive poly( $\mathrm{N}$-isopropylacrylamide-co-acrylic acid) (pNIPAm-co-AAc) hydrogels $[87,112,113]$. A similar approach could be used to make hydrogels attractive for a number of applications as smart materials.

\subsection{Synthesis of Hydrogel Nanoparticles}

A nanogel is a type of hydrogel particle with submicron size that is able to bring additional properties in comparison to bulk hydrogels. For instance, the response rate of pNIPAm nanogel is faster than that of bulk hydrogels. Such nanogels have been prepared by a number of synthetic protocols including precipitation polymerization, miniemulsion polymerization, and microemulsion polymerization $[96,109,114-123]$. The temperature-induced precipitation polymerization method for pNIPAm-co-AAc nanogel has been widely used due to both the water solubility of the precursor monomers and the reduced solubility when polymerized under the absence of oxygen $\left(\mathrm{O}_{2}\right)$ from the reaction mixture (Figure 1). Precipitation polymerization is typically carried out in a three-neck round-bottom flask containing water purged with nitrogen gas. The purge is required to remove any dissolved $\mathrm{O}_{2}$ from the reaction mixture, as $\mathrm{O}_{2}$ acts as a free-radical scavenger that prevents the polymerization reaction from occurring. The solution of main monomer NIPAm and the crosslinker 
$N, N^{\prime}$-methylene(bisacrylamide) (BIS) are stirred and heated above the LCST of the NIPAm. The addition of comonomers into the mixture enables the hydrogels to acquire various functionalities depending on the monomers. Surfactants such as sodium dodecyl sulfate (SDS) and Tween 80 can be used as nanogel stabilizers in these reactions. Note that the modulation of SDS content during a polymerization reaction can be used to control the hydrodynamic radius of the hydrogel.<smiles>C=CC(=O)NC(C)C</smiles>

NIPAm<smiles>C=CC(=O)O</smiles>

AAc<smiles>C=CC(=O)NCNC(=O)C=C</smiles>

BIS

Figure 1. Common monomers used in the synthesis of thermo/pH-responsive microgels. NIPAm: $\mathrm{N}$-isopropylacrylamide, AAc: acrylic acid, BIS: $N, N^{\prime}$-methylenebisacrylamide.

The polymerization reaction can be initiated by adding a free-radical initiator such as ammonium persulfate (APS). The addition of APS produces free radical fragments, which enables them to react with monomers and cross-linkers in the solution. Herein, pNIPAm chains are formed homogenously and then collapsed to form precursor particles when they reach a certain critical chain length. Precursor particles can serve as nuclei for nanogel formation, with a diameter that can be modulated by the amount of surfactant SDS present in the reaction mixture [104,124-126]. For example, a higher SDS concentration results in smaller nanogels until reaching the critical micelle concentration (CMC), while lower SDS concentrations result in larger nanogels. The various stages of nanogel growth during the reaction procedure are illustrated in Figure 2. As discussed previously, numerous comonomers are available that can be added to the reaction mixture to add multiple functionalities to nanogels. Alternatively, polymerized hydrogels can be post-engineered by coupling chemistry, such as carbodiimide reactions, which is widely used to conjugate biological molecules with hydrogels.

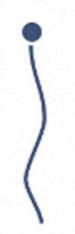

\section{Growing Chain}

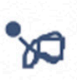
Collapsed Chain

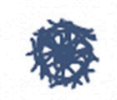
Precursor Particle

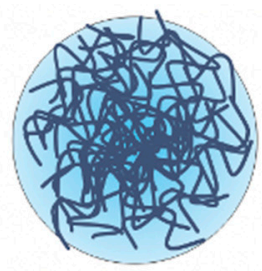

Nanogel Particle

Figure 2. Schematic of the various stages of nanogel growth during precipitation polymerization involving pNIPAm chain growth, which collapse upon reaching a critical chain length. The collapsed chains then serve as precursor particles for growth, resulting in a stable microgel.

\section{Responsivity and Applications of Hydrogels}

\subsection{Responsive Hydrogels}

Unlike non-responsive hydrogels that are simply swollen in the aqueous phase, responsive hydrogels are distinguished and classified as smart materials due to their stimuli-responsive properties $[85,96,110]$. Responsive hydrogels have been extensively developed to design tunable structures that respond to stimuli of interest (Figure 3) $[2,21,32,49,59,65,72,127,128]$. The swelling 
degree in hydrogels is an example of the controlling factors when preparing reversibly responsive hydrogels, which can be modified by adjusting polymer hydrophilicity, network elasticity, and charge density [86,87,110,129].

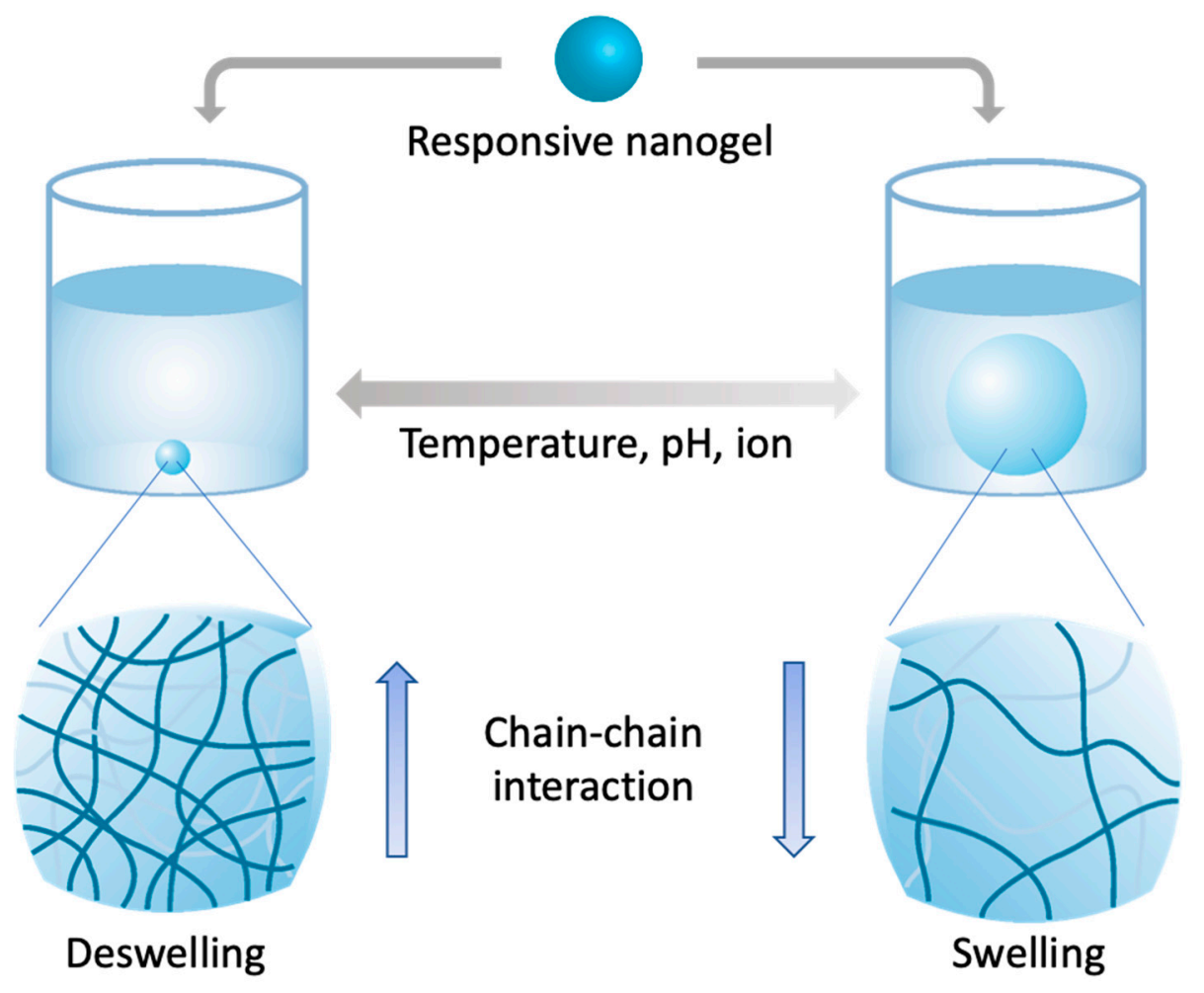

Figure 3. Schematic of a responsive nanogel, where changing temperature, $\mathrm{pH}$, and/or ion in the aqueous phase causes deswelling or swelling of the nanogel.

The swelling/deswelling of polymer networks described by Dusek and Patterson is a fundamental characteristic of responsive hydrogels [110]. In their theoretical estimation, the phase transition of a free swelling gel can be hardly achieved by varying the degree of cross-linking of the polymeric gel and/or dissolved solvent quality, while the phase transition of a polymer network can be achieved easily. Based on their contribution, it might be important to modify the polymer phase transition for the design of hydrogels that are responsive to the adjustment of key factors.

In another study, thermoresponsive ionic gels underwent a discontinuous phase transition of their network, in contrast to a continuous transition by non-ionic gels. It is also interesting to note that the deswelling rate of the ionic gels was inversely proportional to the square of the smallest dimension of the gels [86-88,90,91]. In addition, Yan and Hoffman reported that the polymerization of NIPAm gels at temperatures above the LCST yielded gels with a large pore size [106], which allowed for the production of pNIPAm gels with a rapid swelling rate (Figure 4). In contrast, the hydrogel polymerized at temperatures below the LCST yielded a smaller pore size than that of the hydrogel polymerized above the LCST and had a slower swelling rate. They also suggested that the hydrogel with a large pore size could be useful in drug delivery applications.

Early studies on responsive hydrogels were conducted with the aim of constructing new materials that respond to different stimuli such as $\mathrm{pH}$, temperature, light, and electric field, eventually triggering the phase separation of the polymeric materials $[33,84,87,88,94]$. For instance, a light-responsive hydrogel was formed by copolymerization of the thermoresponsive monomer NIPAm and the light-sensitive chromophore, i.e., trisodium salt of copper chlorophyllin, with a cross-linking agent, which resulted in the phase transition of the gels upon light illumination [94]. In particular, they developed a visible-light-responsive hydrogel where the polymer network was directly heated by the light, which resulted in a rapid transition rate of the hydrogel. Another example of responsive 
hydrogels was shown by applying electric fields to polyacrylamide gels. Herein, an acrylamide group was changed into an acrylic acid group by hydrolysis under electric field, enabling it to provide excess $\mathrm{H}^{+}$ions and thereby increasing Coulomb interactions for the volume phase transition of the acrylamide gel [88]. This study showed that the volume change could be either discrete or continuous depending on the ionization degree of the gel as well as the solvent composition.

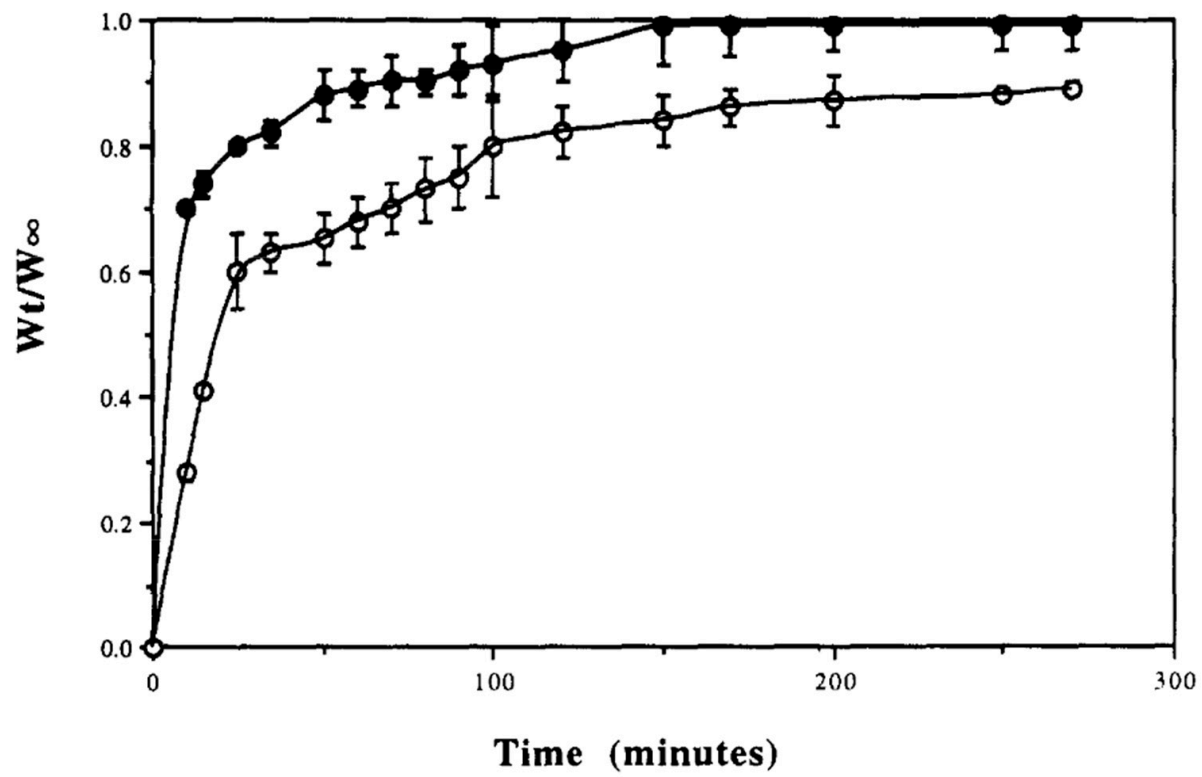

Figure 4. Swelling kinetics of polyNIPAAm hydrogels prepared at above (filled circles) and below (open circles) the lower critical solution temperature (LCST) [106]. Reproduced from [106] with permission. Copyright 1995 Elsevier.

Further efforts have been put into the successful application of responsive polymeric gels in the field of controlled drug release. First, ionic polymer gels including poly(ethyloxazoline) (PEOX, poly(methacrylic acid) (PMAA), or poly(acrylic acid) gels were utilized to capture insulin in a gel matrix. In response to applied electric current, the insulin-loaded matrix released the insulin outward by disrupting the hydrogen bonding of the responsive gels (Figure 5) [33]. Although this work is impractical for real-world applications, the concept of loadable gels responding to external stimuli has been generally cited by other studies in the field of drug release [35,36,63,130-133].

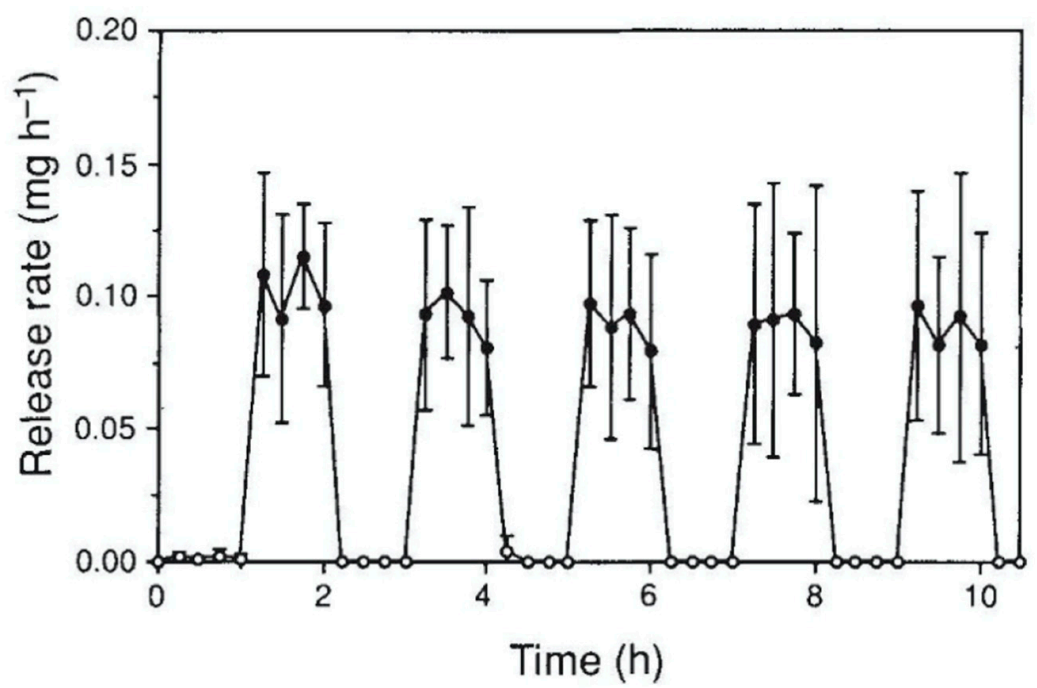

Figure 5. Insulin release rate of insulin-loaded hydrogels as a function of electric current [33]. Reproduced from [33] with permission. Copyright (1991) Springer Nature. 
For responsive hydrogels in chemical sensing, the phase transition of the hydrogels was utilized to construct chemically responsive materials or responsive surface patterns coupled with non-responsive materials $[18,21,24,54]$. One example of a chemical sensing material is to combine a colloidal array of non-responsive polymer spheres with responsive hydrogels during the polymerization process. The hydrogel matrix can be modified with molecular recognition moieties for metal ions, resulting in swelling in response to metal ions due to an increased osmotic pressure of the hydrogel matrix. Therefore, the swelling increases the distance between non-responsive colloidal spheres and shifts the Bragg peak of the diffracted light [21]. This study suggested that a responsive hydrogel as a matrix could be used to facilitate the detection of metal ions by mediating properties of non-responsive materials (Figure 6). However, there is a caveat to using this technique, which requires a high ionic strength of electrolytes and similarly charged metal ions. Hu et al. reported that a thermoresponsive hydrogel (i.e., pNIPAm) can be used to pattern the surface of a non-responsive gel [18]. In this study, the thermoresponsive hydrogel was transformed by changing the temperature, which switched the patterned area from visible to invisible. A limitation of this technique is that it is hardly reproducible in real-world sensing applications due to the slow switching time of $\sim 10 \mathrm{~s}$.

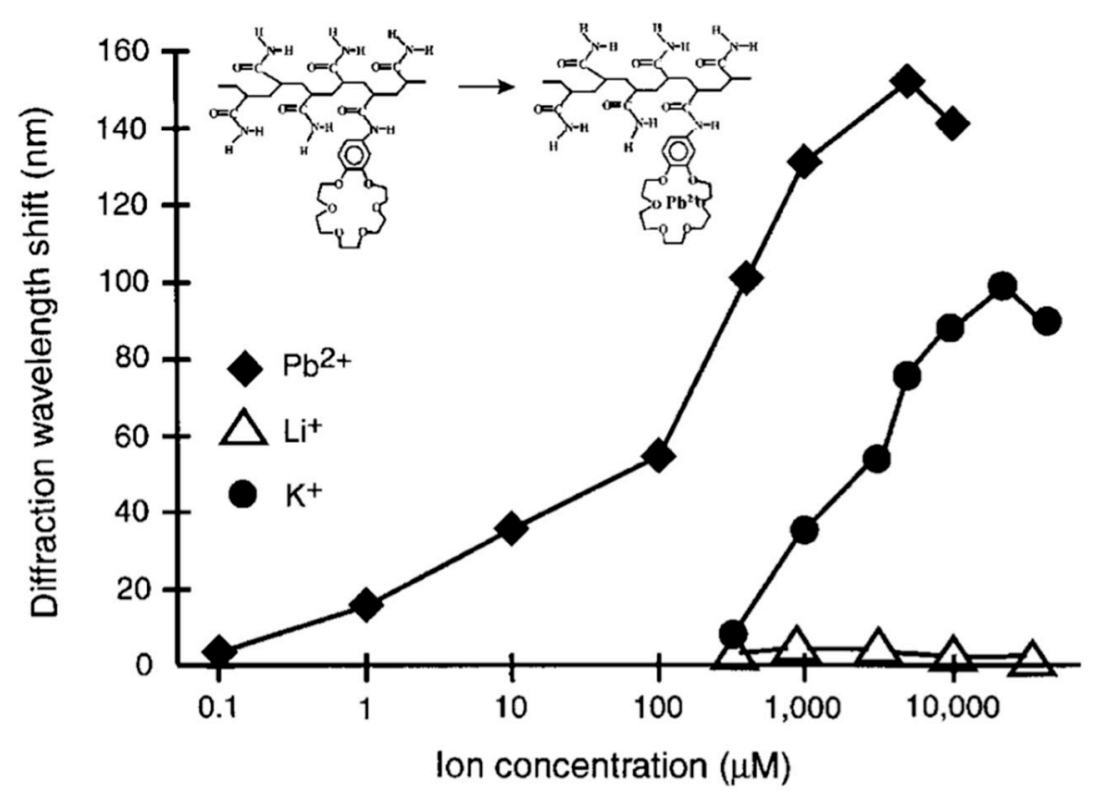

Figure 6. Diffracted wavelength of a polymerized crystalline colloidal arrays (PCCA) sensor as a function of cation concentrations [21]. Reproduced from [21] with permission. Copyright (1997) Springer Nature.

The construction of active components using different types of responsive hydrogel was reported by the Beebe group [12]. Responsive hydrogels were utilized to create a gate component for controlling microfluidic channels via photo-polymerization, which was accomplished by the swelling or deswelling of the hydrogel gate in response to a fluid stream. Interestingly, they proposed that responsive gels at micron scale would have fast response times due to the short diffusion paths, although their construct was macro-scale with a slow response rate. This suggests that microgels (micron-scale hydrogel particles) would be beneficial for developing advanced applications due to their distinct characteristics in response time.

Responsive hydrogel nanoparticles (i.e., colloidally stable particles in nanoscale) are characterized by their smaller size, higher surface area, and, more importantly, faster response time for the volume phase transition than those of macro-scale hydrogels [134]. Such nanoparticles can be synthesized by a precipitation polymerization method, allowing for the formation of thermoresponsive pNIPAm hydrogel nanoparticles with uniform size distribution. Cross-linking density, solvent, and comonomers influence the volume phase transition temperature (VPTT) of hydrogel nanoparticles just as they influence macro-scale hydrogels $[112,113,135]$. For instance, the higher content of acrylic acid (AAc) as a 
comonomer resulted in a higher VPTT of the hydrogel nanoparticles in temperature ramp experiments while BIS as a crosslinker led to a slight increase of the hydrogel VPTT (Figure 7) [136].
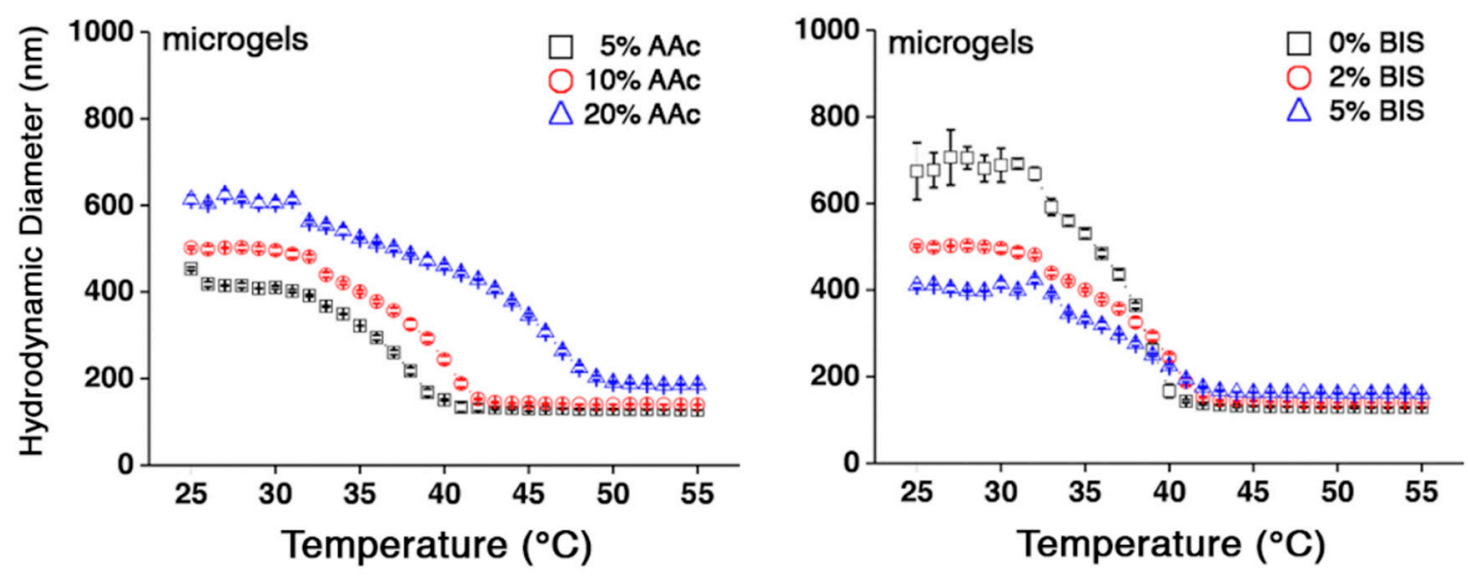

Figure 7. VPTT of hydrogel nanoparticles as a function of AAc and BIS contents in the hydrogel nanoparticles [136]. Reproduced from [136] with permission. Copyright (2018) MDPI AG.

Responsive hydrogel nanoparticles obtained by precipitation polymerization have been extensively investigated for the development of novel responsive materials in upcoming applications. For instance, colloidal crystalline assemblies using thermoresponsive hydrogel nanoparticles were reported which showed tunable phase behavior due to their thermoresponsivity and softness [137-139]. In particular, the behavior of hydrogel crystals was completely reversible through the order-disorder transition in response to temperature changes. The thermoresponsivity of hydrogel nanoparticles allows the crystalline assemblies to be rapidly and widely tunable in response to environment changes including temperature and irradiation. Since the hydrogel nanoparticles experience swelling and deswelling of volume in response to external stimuli, the nanoparticles were utilized to fabricate responsive hydrogel nanoscale optics via electrostatic interactions with no complex fabrication steps $[7,10,64,65]$.

\subsection{Bioresponsive Hydrogels}

Bioresponsive hydrogels that are subject to change in their structure and morphology in response to a biological stimulus have been demonstrated in a number of applications in drug delivery, tissue regeneration, biosensors, and biomimetic systems [5,21,33-52,57-75]. In contrast to simple stimuli-responsive hydrogels, bioresponsive hydrogels that are coupled to biological moieties have been developed by modifying the polymer composition, polymeric structure, and specific functional groups (Figure 8). In this section, bioresponsive hydrogels will be discussed in terms of the types of structural responses to biological stimuli that they exhibit.
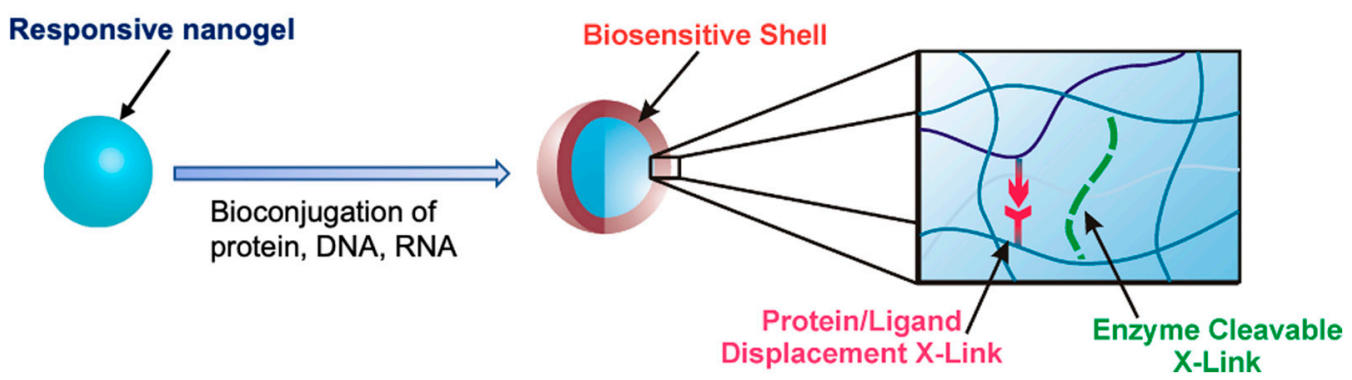

Figure 8. Schematic of a bioresponsive nanogel prepared by conjugating protein, DNA, and RNA to a responsive nanogel. 
Bioresponsive hydrogels can be prepared in a degradable form, which is induced by biological cues such as enzymes. Such hydrogels have been researched extensively to develop smart drug delivery systems and tissue regeneration agents $[42,59,60,140,141]$. In one of these studies, Lutolf et al. reported that hydrogels engineered with an integrin-binding moiety and a matrix metalloproteinase (MMP) substrate were proteolytically degraded by MMP released from human fibroblasts. They also showed that the hydrogel could be used to deliver bone morphogenetic protein-2 (BMP-2) to the defect site in a rat cranium. This could be useful for alternative materials for fibrin or collagen in tissue engineering. Similarly, Kim and Healy reported that degradable pNIPAm-co-AAc hydrogels can be prepared by utilizing the peptide cross-linker and photo-polymerization [142]. In their study, the hydrogels were enzymatically degraded in the presence of collagenase, which was influenced by the concentration of the enzyme and the cross-linking density (Figure 9).

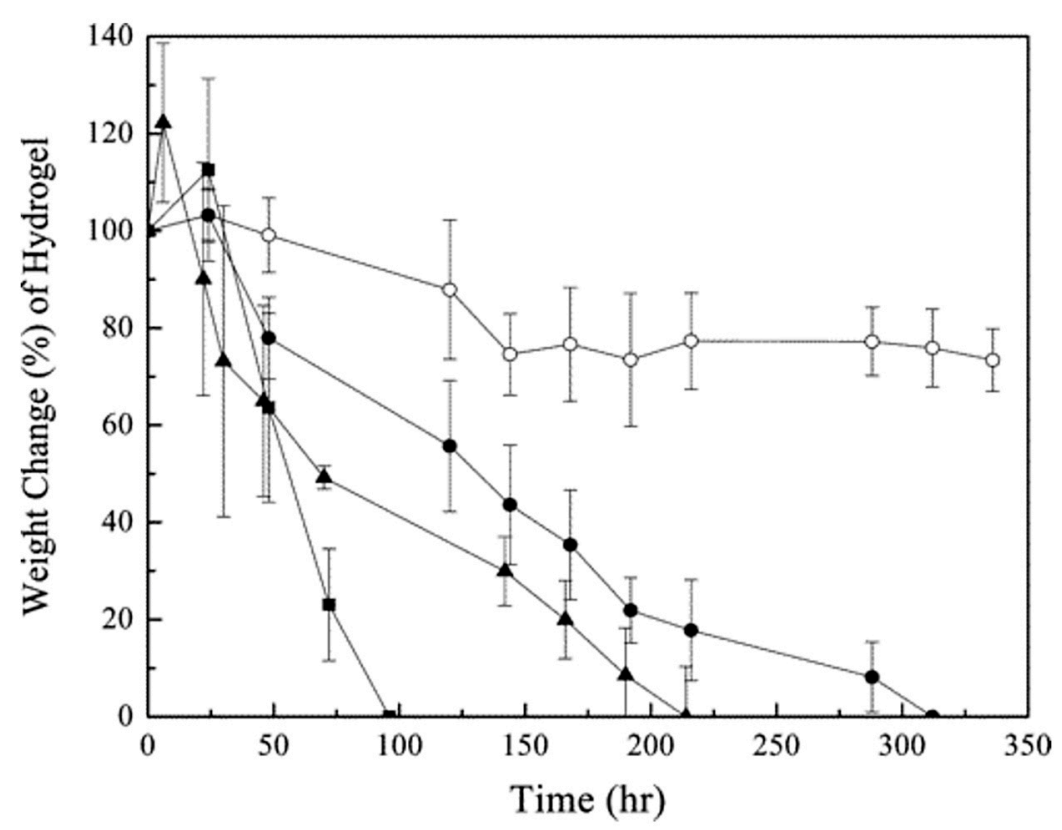

Figure 9. Degradation of peptide-linked pNIPAAm-co-AAc hydrogels with different crosslinkers in collagenase solution [142]. Reproduced from [142] with permission. Copyright (2003) American Chemical Society.

In this category, poly(acrylamide) hydrogels crosslinked with peptides were also developed, which were dissolved in the presence of $\alpha$-chymotrypsin [140]. Such biodegradable hydrogels have potential applications in tissue regeneration as a scaffold material $[59,60]$. In this study, the hydrogel network was functionalized with an integrin binding site and substrate for MMP, which provide the capability of binding to cells and degrading the network, respectively. By exposing the hydrogels to human fibroblasts, cell adhesion, followed by the invasion into the network, was seen through integrin-mediated binding and MMP-linked cleavage. The results suggest that the development of advanced hydrogel systems opens the possibility not only for fundamental studies on cell-matrix interactions but also for biocompatible materials for tissue regeneration. Biodegradable hydrogels with a different application were reported for use in drug delivery where a drug was released by changing the conformation of the hydrogel network [42]. Herein, hydrogels equipped with peptide cross-links were loaded with a chemotherapy drug, which was released by enzymatic cleavage in the presence of MMP (Figure 10). 
A

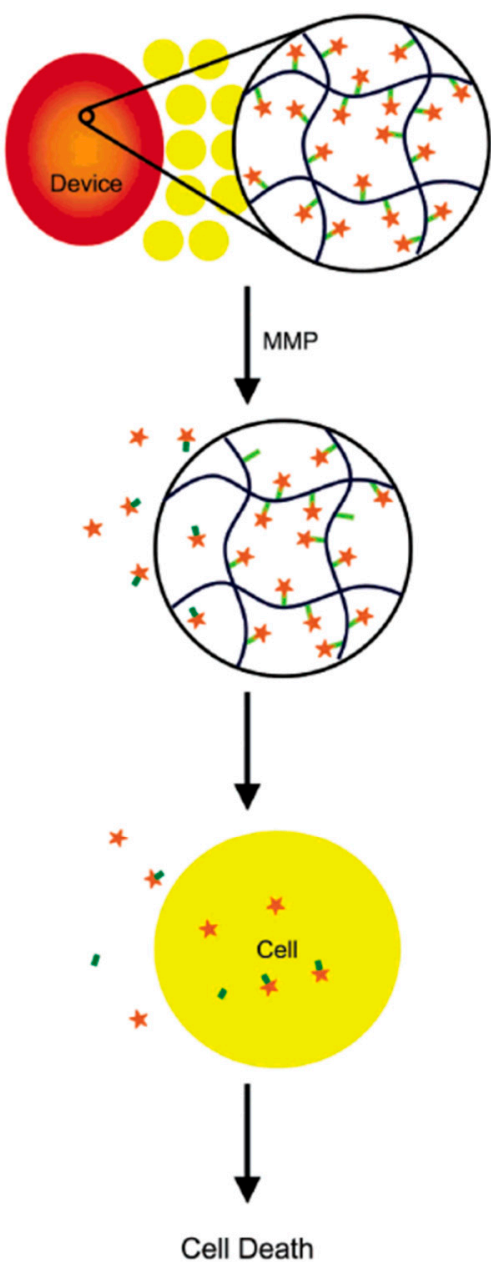

B
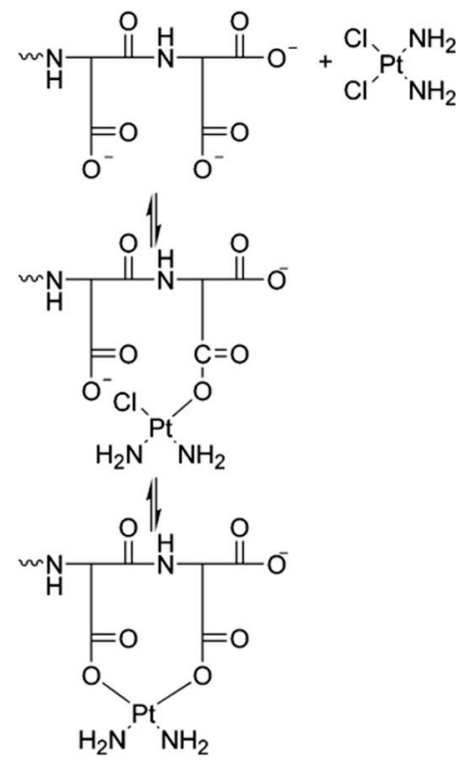

C

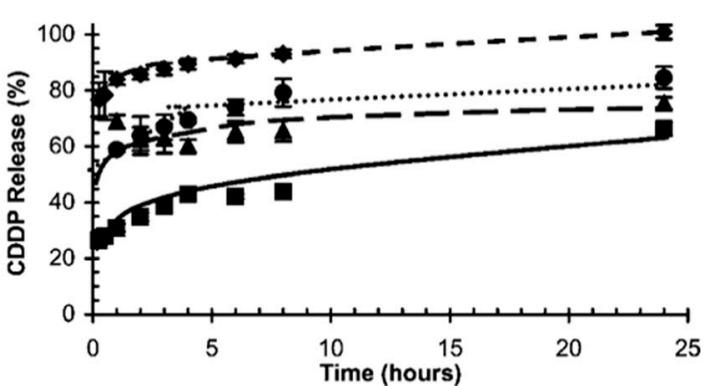

Figure 10. Schematic of cancer chemotherapeutic hydrogel matrixes (a) obtained through the complexation of platinum and aspartic acid linked to peptides in the network (b) and their release from hydrogel matrixes (c) [42] (Reproduced from [42] with permission. Copyright 2005 American Chemical Society). MMP: matrix metalloprotein. CDDP: cisplatin.

Another type of bioresponsive hydrogel could be the biologically inspired gels that mimic biological functions by displaying a specific interaction with a biological moiety. These studies are well described in the fields of cell targeting, protein sieving, and functional substrates to prevent or enhance cell adhesion $[49,53,58,143]$. This kind of bioresponsive hydrogel can be prepared by employing biological pair molecules to the hydrogel network, which allows for the binding of receptors and antibodies to ligand- and antigen-modified hydrogels, respectively. For instance, such hydrogels were used as a targeted drug delivery carrier, where hydrogel nanoparticles were functionalized with folic acid for targeting cancer cells [49]. In this study, the hydrogel nanoparticles were efficiently incorporated into cancer cells through folic acid and its receptor-mediated endocytosis (Figure 11). Similarly, hydrogel nanoparticles were made more sophisticated with both degradable and biological binding capabilities. Nayak and Lyon synthesized core-shell hydrogel nanoparticles by the "seed and feed" method, where the core was conjugated with a ligand and the shell was formed with chemically degradable cross-links. Here, the degradable shell of hydrogel nanoparticles was used to filter proteins by the pore size and then the ligand-labeled core for further binding [53]. These results suggest that the manipulation of the cross-linking density of the hydrogel shell enables one to not only filter proteins of a particular size, but also to reduce the nonspecific binding of larger proteins. 


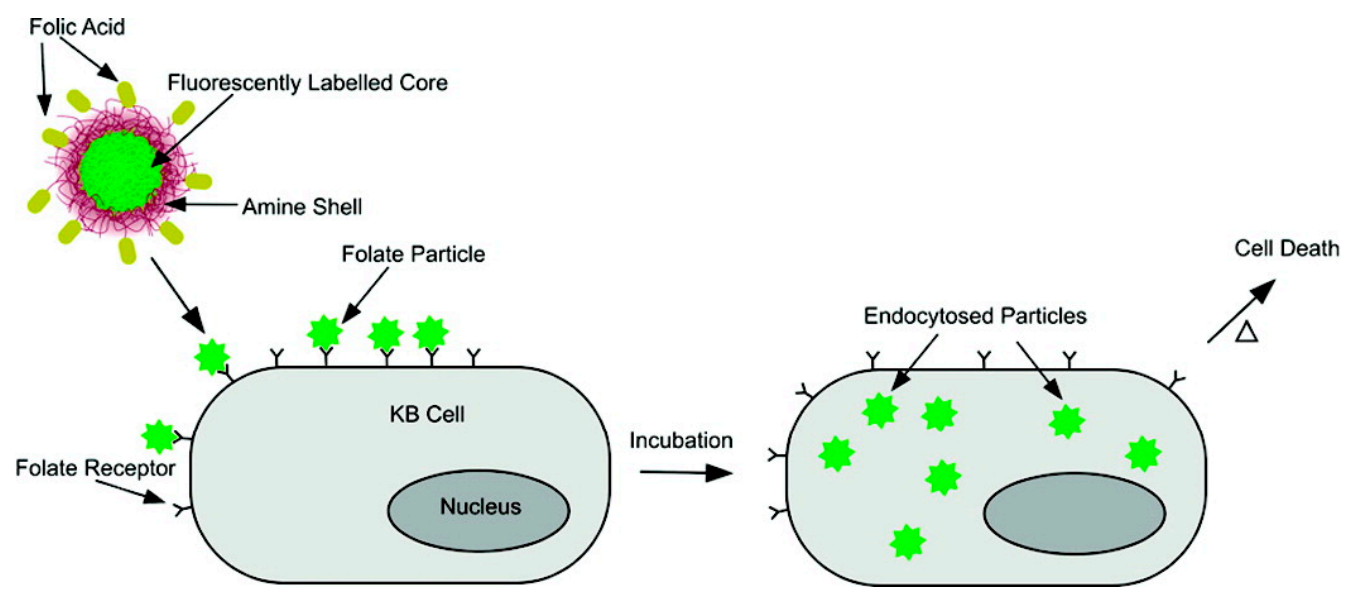

Figure 11. Schematic of targeted pNIPAm hydrogels for cancer cells. The hydrogels are engineered by folic acid to bind with folate receptors on cancer cells [49]. Reproduced from [49] with permission. Copyright (2004) American Chemical Society.

Other studies investigate hydrogels which are reversibly responsive to biological stimuli, where they undergo a change in volume and/or optical property. One potential application of reversibly bioresponsive hydrogels is the construction of biomolecular sensors where a physicochemical change of the hydrogel is observed to determine the binding event of proteins, oligonucleotides, or small molecules $[2,21,64,65,72,144]$. Biomolecular sensing using bioresponsive hydrogels is an example of advanced applications that utilize changes in the optical properties of hydrogels to measure a protein or oligonucleotide binding event. In addition, reversible changes in the properties of bioresponsive hydrogels were demonstrated by engaging antigens and antibodies together into a hydrogel network, providing conceptually breakable and reversible cross-links through antigen-antibody binding $[2,71,72,144]$. Unlike chemical cross-links, the strength of this bond could be adjusted by changing biomolecule pairs that have a broad range of affinity from $\mu \mathrm{M}$ to $\mathrm{pM}$.

When exposed to free-antigen solution, the antigen-antibody cross-links in the hydrogel network could be disrupted by competitive binding of the free antigen, resulting in the reswelling of hydrogels due to a decrease in the degree of cross-linking. Alternatively, the hydrogels could undergo reversible volume change when exposed to a buffer solution by reformation of the cross-link due to the release of bound free antigen. Similarly, a bioresponsive hydrogel was utilized to recognize tumor-specific marker glycoprotein (i.e., $\alpha$-fetoprotein (AFP)), where the hydrogel was constructed using the imprinting of a lectin-AFP-antibody complex [2]. Here, the imprinted hydrogel displayed a response to the tumor marker by decreasing volume in the presence of the AFP (Figure 12).

In spite of these interesting studies, there are remaining issues. For example, the response time is very slow, $\sim 1 \mathrm{~h}$, and the volume change is small, about $5 \%$, which hamper the applications of the hydrogel system for real-world applications. Such limitations could be improved by using nanosized hydrogel systems because nanogels have a faster phase transition time than bulk gels. For instance, bioresponsive nanogels were utilized to functionalize the gold surface of a biochip for surface plasmon resonance (SPR) analysis, where responsive nanogels were conjugated with an immune check-point protein (i.e., PD-1), and PD-1 antibody was measured with high selectivity [144]. This work demonstrated that responsive nanogels could be used not only to recognize the molecular mechanism of protein binding, but also to screen a target antibody in biological media (Figure 13). 


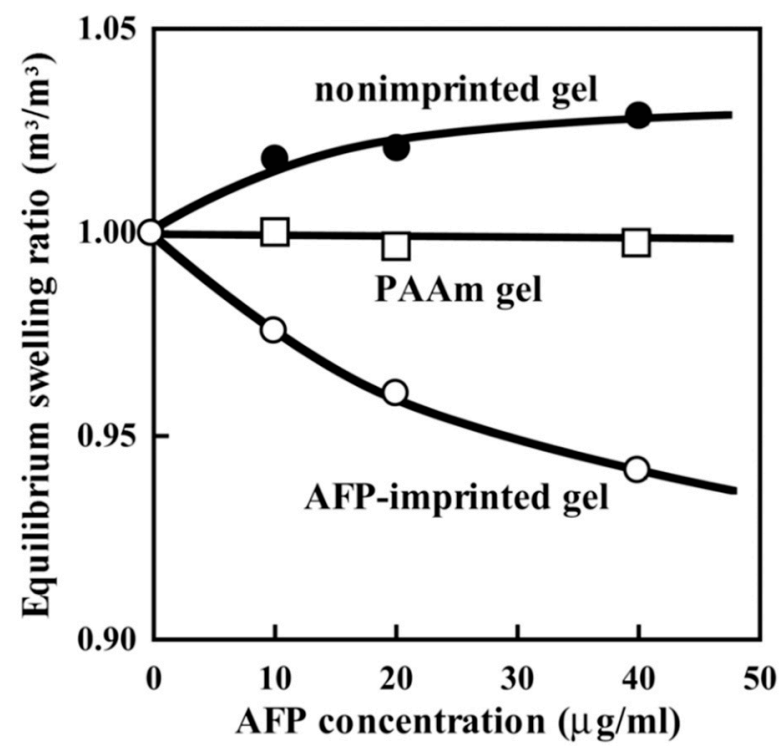

Figure 12. Swelling behavior of $\alpha$-fetoprotein (AFP)-imprinted hydrogels in the presence of free AFP in solution [2] (Reproduced from [2] with permission. Copyright (2006) National Academy of Sciences.) PAAm: poly(acrylamide).
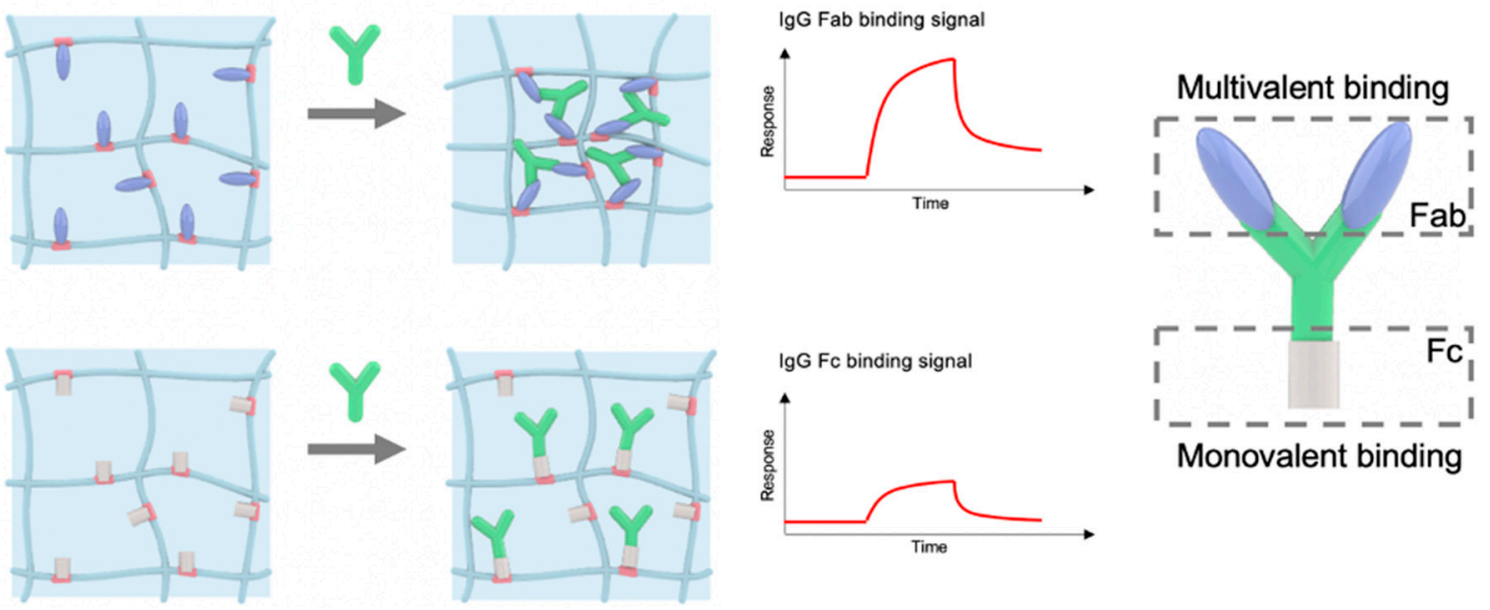

Figure 13. Schematic of an antibody-responsive nanogel and its application for surface plasmon resonance (SPR) analysis.

\section{Conclusions}

In this review, we introduced and discussed responsive hydrogels, particularly bioresponsive nanogels that allow for the design of a novel platform in which responsivity is correlated with a specialized task in response to a biological event. The composition of and synthetic methods for the achievement of bioresponsive nanogels were discussed, linking them with the responsivity of the nanogels. Then, a number of applications using responsive and bioresponsive hydrogels were reviewed to present the utility of these materials in many fields. While these hydrogels and nanogels have been successfully applied for novel biological applications, including controlled drug delivery systems, biosensing, and tissue engineering, they are still of great interest for developing more sophisticated nanogels that have specialized capabilities with more complex responsivities.

Author Contributions: Conceptualization, H.C.; investigation, H.C., S.J., J.Y., S.Y.B., and D.K.; resources, H.C., S.J., J.Y., S.Y.B., and D.K.; data curation, H.C., S.J., J.Y., S.Y.B., and D.K.; writing-original draft preparation, H.C., S.J., J.Y., S.Y.B., and D.K.; writing-review \& editing, H.C.; supervision, H.C.; project administration, H.C. All authors have read and agreed to the published version of the manuscript. 
Funding: This research received no external funding.

Acknowledgments: We acknowledge the intern program of Scholar Foxtrot Co., Ltd.

Conflicts of Interest: The authors declare no conflicts of interest.

\section{References}

1. Hoffman, A.S. Hydrogels for biomedical applications. Adv. Drug Deliv. Rev. 2002, 54, 3-12. [CrossRef]

2. Miyata, T.; Jige, M.; Nakaminami, T.; Uragami, T. Tumor marker-responsive behavior of gels prepared by biomolecular imprinting. Proc. Natl. Acad. Sci. USA 2006, 103, 1190-1193. [CrossRef] [PubMed]

3. Hennink, W.E.; van Nostrum, C.F. Novel crosslinking methods to design hydrogels. Adv. Drug Deliv. Rev. 2002, 54, 13-36. [CrossRef]

4. Yeomans, K. Hydrogels-Very versatile materials. Chem. Rev. 2000, 10, 2-5.

5. Drury, J.L.; Mooney, D.J. Hydrogels for tissue engineering: Scaffold design variables and applications. Biomaterials 2003, 24, 4337-4351. [CrossRef]

6. DeRossi, D.; Kajiwara, K.; Osada, Y.; Yamauchi, A. Polymer Gels. Fundamentals and Biomedical Applications; Plenum Press: New York, NY, USA, 1991.

7. Kim, J.; Serpe, M.J.; Lyon, L.A. Photoswitchable microlens arrays. Angew. Chem. Int. Ed. 2005, 44, $1333-1336$. [CrossRef]

8. Dong, L.; Agarwal Abhishek, K.; Beebe David, J.; Jiang, H. Adaptive liquid microlenses activated by stimuli-responsive hydrogels. Nature 2006, 442, 551-554. [CrossRef]

9. Serpe, M.J.; Kim, J.; Lyon, L.A. Colloidal hydrogel microlenses. Adv. Mater. 2004, 16, 184-187. [CrossRef]

10. Kim, J.; Serpe, M.J.; Lyon, L.A. Hydrogel microparticles as dynamically tunable microlenses. J. Am. Chem. Soc. 2004, 126, 9512-9513. [CrossRef]

11. Reese, C.E.; Mikhonin, A.V.; Kamenjicki, M.; Tikhonov, A.; Asher, S.A. Nanogel nanosecond photonic crystal optical switching. J. Am. Chem. Soc. 2004, 126, 1493-1496. [CrossRef]

12. Beebe, D.J.; Moore, J.S.; Bauer, J.M.; Yu, Q.; Liu, R.H.; Devadoss, C.; Jo, B.-H. Functional hydrogel structures for autonomous flow control inside microfluidic channels. Nature 2000, 404, 588-590. [CrossRef] [PubMed]

13. Atencia, J.; Beebe, D.J. Controlled microfluidic interfaces. Nature 2005, 437, 648-655. [CrossRef] [PubMed]

14. Yu, Q.; Bauer, J.M.; Moore, J.S.; Beebe, D.J. Responsive biomimetic hydrogel valve for microfluidics. Appl. Phys. Lett. 2001, 78, 2589-2591. [CrossRef]

15. Eddington, D.T.; Beebe, D.J. Flow control with hydrogels. Adv. Drug Deliv. Rev. 2004, 56, 199-210. [CrossRef] [PubMed]

16. Zhao, B.; Moore, J.S. Fast pH- and ionic strength-responsive hydrogels in microchannels. Langmuir 2001, 17, 4758-4763. [CrossRef]

17. Arndt, K.F.; Kuckling, D.; Richter, A. Application of sensitive hydrogels in flow control. Polym. Adv. Technol. 2000, 11, 496-505. [CrossRef]

18. Hu, Z.; Chen, Y.; Wang, C.; Zheng, Y.; Li, Y. Polymer gels with engineered environmentally responsive surface patterns. Nature 1998, 393, 149-152. [CrossRef]

19. Galindo, F.; Lima, J.C.; Luis, S.V.; Parola, A.J.; Pina, F. Write-read-erase molecular-switching system trapped in a polymer hydrogel matrix. Adv. Funct. Mater. 2005, 15, 541-545. [CrossRef]

20. Suh, K.Y.; Langer, R.; Lahann, J. A novel photoderinable reactive polymer coating and its use for microfabrication of hydrogel elements. Adv. Mater. 2004, 16, 1401-1405. [CrossRef]

21. Holtz, J.H.; Asher, S.A. Polymerized colloidal crystal hydrogel films as intelligent chemical sensing materials. Nature 1997, 389, 829-832. [CrossRef]

22. Yoshimura, I.; Miyahara, Y.; Kasagi, N.; Yamane, H.; Ojida, A.; Hamachi, I. Molecular recognition in a supramolecular hydrogel to afford a semi-wet sensor chip. J. Am. Chem. Soc. 2004, 126, 12204-12205. [CrossRef] [PubMed]

23. Lee, M.-C.; Kabilan, S.; Hussain, A.; Yang, X.; Blyth, J.; Lowe, C.R. Glucose-sensitive holographic sensors for monitoring bacterial growth. Anal. Chem. 2004, 76, 5748-5755. [CrossRef] [PubMed]

24. Holtz, J.H.; Holtz, J.S.W.; Munro, C.H.; Asher, S.A. Intelligent polymerized crystalline colloidal arrays: Novel chemical sensor materials. Anal. Chem. 1998, 70, 780-791. [CrossRef]

25. Liu, L.; Li, P.; Asher, S.A. Entropic trapping of macromolecules by mesoscopic periodic voids in a polymer hydrogel. Nature 1999, 397, 141-144. [CrossRef] [PubMed] 
26. Lee, K.; Asher, S.A. Photonic crystal chemical sensors: $\mathrm{pH}$ and ionic strength. J. Am. Chem. Soc. 2000, 122, 9534-9537. [CrossRef]

27. Asher, S.A.; Sharma, A.C.; Goponenko, A.V.; Ward, M.M. Photonic crystal aqueous metal cation sensing materials. Anal. Chem. 2003, 75, 1676-1683. [CrossRef]

28. Alvarez-Lorenzo, C.; Guney, O.; Oya, T.; Sakai, Y.; Kobayashi, M.; Enoki, T.; Takeoka, Y.; Ishibashi, T.; Kuroda, K.; Tanaka, K.; et al. Reversible adsorption of calcium ions by imprinted temperature sensitive gels. J. Chem. Phys. 2001, 114, 2812-2816. [CrossRef]

29. Bergbreiter, D.E.; Liu, Y.-S.; Osburn, P.L. Thermomorphic rhodium(I) and palladium(0) catalysts. J. Am. Chem. Soc. 1998, 120, 4250-4251. [CrossRef]

30. Bergbreiter, D.E.; Case, B.L.; Liu, Y.-S.; Caraway, J.W. Poly(N-isopropylacrylamide) soluble polymer supports in catalysis and synthesis. Macromolecules 1998, 31, 6053-6062. [CrossRef]

31. Nagayama, H.; Maeda, Y.; Shimasaki, C.; Kitano, H. Catalytic properties of enzymes modified with temperature-responsive polymer-chains. Macromol. Chem. Phys. 1995, 196, 611-620. [CrossRef]

32. Shimoboji, T.; Larenas, E.; Fowler, T.; Kulkarni, S.; Hoffman, A.S.; Stayton, P.S. Photoresponsive polymer-enzyme switches. Proc. Natl. Acad. Sci. USA 2002, 99, 16592-16596. [CrossRef] [PubMed]

33. Kwon, I.C.; Bae, Y.H.; Kim, S.W. Electrically erodible polymer gel for controlled release of drugs. Nature 1991, 354, 291-293. [CrossRef] [PubMed]

34. Kim, S.W.; Bae, Y.H.; Okano, T. Hydrogels: Swelling, drug loading, and release. Pharm. Res. 1992, 9, $283-290$. [CrossRef] [PubMed]

35. Jeong, B.; Bae, Y.H.; Lee, D.S.; Kim, S.W. Biodegradable block copolymers as injectable drug-delivery systems. Nature 1997, 388, 860-862. [CrossRef]

36. Peppas, N.A. Hydrogels and drug delivery. Curr. Opin. Colloid Interface Sci. 1997, 2, 531-537. [CrossRef]

37. Langer, R. Drug delivery and targeting. Nature 1998, 392, 5-10.

38. Park, T.G. Temperature modulated protein release from $\mathrm{pH} /$ temperature-sensitive hydrogels. Biomaterials 1999, 20, 517-521. [CrossRef]

39. Kikuchi, A.; Okano, T. Pulsatile drug release control using hydrogels. Adv. Drug Delivery Rev. 2002, 54, 53-77. [CrossRef]

40. Nolan, C.M.; Serpe, M.J.; Lyon, L.A. Thermally modulated insulin release from microgel thin films. Biomacromolecules 2004, 5, 1940-1946. [CrossRef]

41. Serpe, M.J.; Yarmey, K.A.; Nolan, C.M.; Lyon, L.A. Doxorubicin uptake and release from microgel thin films. Biomacromolecules 2005, 6, 408-413. [CrossRef]

42. Tauro, J.R.; Gemeinhart, R.A. Matrix metalloprotease triggered delivery of cancer chemotherapeutics from hydrogel matrixes. Bioconjugate Chem. 2005, 16, 1133-1139. [CrossRef] [PubMed]

43. Cheng, J.; Teply, B.A.; Jeong, S.Y.; Yim, C.H.; Ho, D.; Sherifi, I.; Jon, S.; Farokhzad, O.C.; Khademhosseini, A.; Langer, R.S. Magnetically responsive polymeric microparticles for oral delivery of protein drugs. Pharm. Res. 2006, 23, 557-564. [CrossRef] [PubMed]

44. LaVan, D.A.; McGuire, T.; Langer, R. Small-scale systems for in vivo drug delivery. Nat. Biotechnol. 2003, 21, 1184-1191. [CrossRef] [PubMed]

45. Murthy, N.; Thng, Y.X.; Schuck, S.; Xu, M.C.; Frechet, J.M.J. A novel strategy for encapsulation and release of proteins: Hydrogels and microgels with acid-labile acetal cross-linkers. J. Am. Chem. Soc. 2002, 124, 12398-12399. [CrossRef] [PubMed]

46. Gupta, P.; Vermani, K.; Garg, S. Hydrogels: From controlled release to pH-responsive drug delivery. Drug Discov. Today 2002, 7, 569-579. [CrossRef]

47. Qiu, Y.; Park, K. Environment-sensitive hydrogels for drug delivery. Adv. Drug Deliv. Rev. 2001, 53, 321-339. [CrossRef]

48. Moselhy, J.; Wu, X.Y.; Nicholov, R.; Kodaria, K. In vitro studies of the interaction of poly(NIPAm/MAA) nanoparticles with proteins and cells. J. Biomater. Sci. Polym. Ed. 2000, 11, 123-147. [CrossRef]

49. Nayak, S.; Lee, H.; Chmielewski, J.; Lyon, L.A. Folate-mediated cell targeting and cytotoxicity using thermoresponsive microgels. J. Am. Chem. Soc. 2004, 126, 10258-10259. [CrossRef]

50. Uhrich, K.E.; Cannizzaro, S.M.; Langer, R.S.; Shakesheff, K.M. Polymeric systems for controlled drug release. Chem. Rev. Wash. 1999, 99, 3181-3198. [CrossRef]

51. Kiser, P.F.; Wilson, G.; Needham, D. A synthetic mimic of the secretory granule for drug delivery. Nature 1998, 394, 459-462. [CrossRef] 
52. Sato, K.; Kodama, D.; Naka, Y.; Anzai, J.-I. Electrochemically induced disintegration of layer-by-layer-assembled thin films composed of 2-iminobiotin-labeled poly(ethyleneimine) and avidin. Biomacromolecules 2006, 7, 3302-3305. [CrossRef] [PubMed]

53. Nayak, S.; Lyon, L.A. Ligand-functionalized core/shell microgels with permselective shells. Angew. Chem. Int. Ed. 2004, 43, 6706-6709. [CrossRef] [PubMed]

54. Kim, J.J.; Park, K. Smart hydrogels for bioseparation. Bioseparation 1998, 7, 177-184. [CrossRef] [PubMed]

55. Kawaguchi, H.; Fujimoto, K. Smart latexes for bioseparation. Bioseparation 1998, 7, 253-258. [CrossRef]

56. Yaszemski, M.J.; Payne, R.G.; Hayes, W.C.; Langer, R.S.; Aufdemorte, T.B.; Mikos, A.G. The ingrowth of new bone tissue and initial mechanical properties of a degrading polymeric composite scaffold. Tissue Eng. 1995, 1, 41-52. [CrossRef]

57. Luo, Y.; Shoichet, M.S. A photolabile hydrogel for guided three-dimensional cell growth and migration. Nat. Mater. 2004, 3, 249-253. [CrossRef]

58. Lutolf, M.P.; Raeber, G.P.; Zisch, A.H.; Tirelli, N.; Hubbell, J.A. Cell-responsive synthetic hydrogels. Adv. Mater. 2003, 15, 888-892. [CrossRef]

59. Lutolf, M.P.; Lauer-Fields, J.L.; Schmoekel, H.G.; Metters, A.T.; Weber, F.E.; Fields, G.B.; Hubbell, J.A. Synthetic matrix metalloproteinase-sensitive hydrogels for the conduction of tissue regeneration: Engineering cell-invasion characteristics. Proc. Natl. Acad. Sci. USA 2003, 100, 5413-5418. [CrossRef]

60. Choi, S.H.; Yoon, J.J.; Park, T.G. Galactosylated poly(N-isopropylacrylamide) hydrogel submicrometer particles for specific cellular uptake within hepatocytes. J. Colloid Interface Sci. 2002, 251, 57-63. [CrossRef]

61. Jen, A.C.; Wake, M.C.; Mikos, A.G. Review: Hydrogels for cell immobilization. Biotechnol. Bioeng. 1996, 50, 357-364. [CrossRef]

62. Lee, K.Y.; Peters, M.C.; Anderson, K.W.; Mooney, D.J. Controlled growth factor release from synthetic extracellular matrices. Nature 2000, 408, 998-1000. [CrossRef]

63. Kim, J.; Singh, N.; Lyon, L.A. Label-free biosensing with hydrogel microlenses. Angew. Chem. Int. Ed. 2006, 45, 1446-1449. [CrossRef] [PubMed]

64. Kim, J.; Nayak, S.; Lyon, L.A. Bioresponsive hydrogel microlenses. J. Am. Chem. Soc. 2005, 127, 9588-9592. [CrossRef] [PubMed]

65. Asher, S.A.; Alexeev, V.L.; Goponenko, A.V.; Sharma, A.C.; Lednev, I.K.; Wilcox, C.S.; Finegold, D.N. Photonic crystal carbohydrate sensors: Low ionic strength sugar sensing. J. Am. Chem. Soc. 2003, 125, 3322-3329. [CrossRef] [PubMed]

66. Alexeev, V.L.; Sharma, A.C.; Goponenko, A.V.; Das, S.; Lednev, I.K.; Wilcox, C.S.; Finegold, D.N.; Asher, S.A. High ionic strength glucose-sensing photonic crystal. Anal. Chem. 2003, 75, 2316-2323. [CrossRef]

67. Walker, J.P.; Asher, S.A. Acetylcholinesterase-based organophosphate nerve agent sensing photonic crystal. Anal. Chem. 2005, 77, 1596-1600. [CrossRef]

68. Ben-Moshe, M.; Alexeev, V.L.; Asher, S.A. Fast responsive crystalline colloidal array photonic crystal glucose sensors. Anal. Chem. 2006, 78, 5149-5157. [CrossRef]

69. Lu, Z.-R.; Kopeckova, P.; Kopecek, J. Antigen responsive hydrogels based on polymerizable antibody fab' fragment. Macromol. Biosci. 2003, 3, 296-300. [CrossRef]

70. Miyata, T.; Uragami, T.; Nakamae, K. Biomolecule-sensitive hydrogels. Adv. Drug Deliv. Rev. 2002, 54, 79-98. [CrossRef]

71. Miyata, T.; Asami, N.; Uragami, T. A reversibly antigen-responsive hydrogel. Nature 1999, 399, 766-769. [CrossRef]

72. Kataoka, K.; Miyazaki, H.; Bunya, M.; Okano, T.; Sakurai, Y. Totally synthetic polymer gels responding to external glucose concentration: Their preparation and application to on-off regulation of insulin release. J. Am. Chem. Soc. 1998, 120, 12694-12695. [CrossRef]

73. Hassan, C.M.; Doyle, F.J.; Peppas, N.A. Dynamic behavior of glucose-responsive poly(methacrylic acid-G-ethylene glycol) hydrogels. Macromolecules 1997, 30, 6166-6173. [CrossRef]

74. Sharma, A.C.; Jana, T.; Kesavamoorthy, R.; Shi, L.; Virji, M.A.; Finegold, D.N.; Asher, S.A. A general photonic crystal sensing motif: Creatinine in bodily fluids. J. Am. Chem. Soc. 2004, 126, 2971-2977. [CrossRef] [PubMed]

75. Akiyoshi, K.; Kang, E.-C.; Kurumada, S.; Sunamoto, J.; Principi, T.; Winnik, F.M. Controlled association of amphiphilic polymers in water: Thermosensitive nanoparticles formed by self-assembly of hydrophobically modified pullulans and poly(N-isopropylacrylamides). Macromolecules 2000, 33, 3244-3249. [CrossRef] 
76. Collier, J.H.; Hu, B.-H.; Ruberti, J.W.; Zhang, J.; Shum, P.; Thompson, D.H.; Messersmith, P.B. Thermally and photochemically triggered self-assembly of peptide hydrogels. J. Am. Chem. Soc. 2001, 123, 9463-9464. [CrossRef] [PubMed]

77. Eagland, D.; Crowther, N.J.; Butler, C.J. Complexation between polyoxyethylene and poly(methacrylic acid). The importance of the molar mass of polyoxyethylene. Eur. Polym. J. 1994, 30, 767-773. [CrossRef]

78. Mathur, A.M.; Hammonds, K.F.; Klier, J.; Scranton, A.B. Equilibrium swelling of poly(methacrylic acid-G-ethylene glycol) hydrogels effect of swelling medium and synthesis conditions. J. Control. Release 1998, 54, 177-184. [CrossRef]

79. Watanabe, T.; Ohtsuka, A.; Murase, N.; Barth, P.; Gersonde, K. NMR studies on water and polymer diffusion in dextran gels. Influence of potassium ions on microstructure formation and gelation mechanism. Magnet. Reson. Med. 1996, 35, 697-705. [CrossRef]

80. Gacesa, P. Alginates. Carbohyd. Polym. 1988, 8, 161-182. [CrossRef]

81. Gombotz, W.R.; Wee, S. Protein release from alginate matrixes. Adv. Drug Deliv. Rev. 1998, 31, $267-285$. [CrossRef]

82. Goosen, M.F.A.; O'Shea, G.M.; Gharapetian, H.M.; Chou, S.; Sun, A.M. Optimization of microencapsulation parameters: Semipermeable microcapsules as a bioartificial pancreas. Biotechnol. Bioeng. 1985, 27, 146-150. [CrossRef] [PubMed]

83. Heskins, M.; Guillet, J.E. Solution properties of poly(N-isopropylacrylamide). J. Macromol. Sci. Chem. 1968, 2, 1441-1455. [CrossRef]

84. Tanaka, T. Collapse of gels and the critical endpoint. Phys. Rev. Lett. 1978, 40, 820-823. [CrossRef]

85. Tanaka, T.; Fillmore, D.J. Kinetics of swelling of gels. J. Chem. Phys. 1979, 70, 1214-1218. [CrossRef]

86. Tanaka, T.; Fillmore, D.J.; Sun, S.-T.; Nishio, I.; Swislow, G.; Shah, A. Phase transition in ionic gels. Phys. Rev. Lett. 1980, 45, 1636-1639. [CrossRef]

87. Tanaka, T.; Nishio, I.; Sun, S.T.; Uenonishio, S. Collapse of gels in an electric-field. Science 1982, 218, 467-469. [CrossRef]

88. Tanaka, T.; Sato, E.; Hirokawa, Y.; Hirotsu, S.; Peetermans, J. Critical kinetics of volume phase transition of gels. Phys. Rev. Lett. 1985, 55, 2455-2458. [CrossRef]

89. Tanaka, T. Kinetics of phase transition in polymer gels. Phys. A 1986, 140, 261-268. [CrossRef]

90. Matsuo, E.S.; Tanaka, T. Kinetics of discontinuous volume-phase transition of gels. J. Chem. Phys. 1988, 89, 1695-1703. [CrossRef]

91. Inomata, H.; Goto, S.; Saito, S. Phase transition of N-substituted acrylamide gels. Macromolecules 1990, 23, 4887-4888. [CrossRef]

92. Li, Y.; Tanaka, T. Kinetics of swelling and shrinking of gels. J. Chem. Phys. 1990, 92, 1365-1371. [CrossRef]

93. Suzuki, A.; Tanaka, T. Phase-transition in polymer gels induced by visible-light. Nature 1990, 346, $345-347$. [CrossRef]

94. Wu, C.; Zhou, S. Laser light scattering study of the phase transition of poly(N-isopropylacrylamide) in water. 1. Single Chain. Macromolecules 1995, 28, 8381-8387. [CrossRef]

95. Pelton, R. Temperature-sensitive aqueous microgels. Adv. Colloid Interface Sci. 2000, 85, 1-33. [CrossRef]

96. Wang, J.P.; Gan, D.J.; Lyon, L.A.; El-Sayed, M.A. Temperature-jump investigations of the kinetics of hydrogel nanoparticle volume phase transitions. J. Am. Chem. Soc. 2001, 123, 11284-11289. [CrossRef]

97. Jones, C.D.; Lyon, L.A. Photothermal patterning of microgel/gold nanoparticle composite colloidal crystals. J. Am. Chem. Soc. 2003, 125, 460-465. [CrossRef]

98. Jones, C.D.; Serpe, M.J.; Schroeder, L.; Lyon, L.A. Microlens formation in microgel/gold colloid composite materials via photothermal patterning. J. Am. Chem. Soc. 2003, 125, 5292-5293. [CrossRef]

99. Nayak, S.; Debord, S.B.; Lyon, L.A. Investigations into the deswelling dynamics and thermodynamics of thermoresponsive microgel composite films. Langmuir 2003, 19, 7374-7379. [CrossRef]

100. Nayak, S.; Lyon, L.A. Photoinduced phase transitions in poly(N-isopropylacrylamide) microgels. Chem. Mater. 2004, 16, 2623-2627. [CrossRef]

101. Nayak, S.; Lyon, L.A. Soft nanotechnology with soft nanoparticles. Angew. Chem. Int. Ed. 2005, 44, 7686-7708. [CrossRef]

102. Zhou, G.; Elaissari, A.; Delair, T.; Pichot, C. Synthesis and characterization of surface-cyanofunctionalized poly(N-isopropylacrylamide) latexes. Colloid Polym. Sci. 1998, 276, 1131-1139. [CrossRef] 
103. McPhee, W.; Tam, K.C.; Pelton, R. Poly(N-isopropylacrylamide) latexes prepared with sodium dodecyl sulfate. J. Colloid Interface Sci. 1993, 156, 24-30. [CrossRef]

104. Park, T.G.; Hoffman, A.S. Deswelling characteristics of poly(N-isopropylacrylamide) hydrogel. J. Appl. Polym. Sci. 1994, 52, 85-89. [CrossRef]

105. Yan, Q.; Hoffman, A.S. Synthesis of macroporous hydrogels with rapid swelling and deswelling properties for delivery of macromolecules. Poly. Commun. 1995, 36, 887-889. [CrossRef]

106. Varga, I.; Gilanyi, T.; Meszaros, R.; Filipcsei, G.; Zrinyi, M. Effect of cross-link density on the internal structure of poly(N-isopropylacrylamide) microgels. J. Phys. Chem. B 2001, 105, 9071-9076. [CrossRef]

107. Hu, T.J.; You, Y.Z.; Pan, C.Y.; Wu, C. The coil-to-globule-to-brush transition of linear thermally sensitive poly(N-isopropylacrylamide) chains grafted on a spherical microgel. J. Phys. Chem. B 2002, 106, 6659-6662. [CrossRef]

108. Guo, Z.L.; Wang, J.T.; Zhu, H.J. Preparation of temperature sensitive ultrafine particles of poly(N-isopropyl acrylamide) by microemulsion polymerization. Acta Polym. Sin. 2001, 4, 489-493.

109. Dusek, K.; Patterson, K. Transition on swollen polymer networks induced by intramolecular condensation. J. Polym. Sci. Polym. Phys. Ed. 1968, 6, 1209-1216.

110. Arotcarena, M.; Heise, B.; Ishaya, S.; Laschewsky, A. Switching the inside and the outside of aggregates of water-soluble block copolymers with double thermoresponsivity. J. Am. Chem. Soc. 2002, 124, 3787-3793. [CrossRef]

111. Jones, C.D.; Lyon, L.A. Synthesis and characterization of multiresponsive core-shell microgels. Macromolecules 2000, 33, 8301-8306. [CrossRef]

112. Jones, C.D.; Lyon, L.A. Shell-restricted swelling and core compression in poly(N-isopropylacrylamide) core-shell microgels. Macromolecules 2003, 36, 1988-1993. [CrossRef]

113. Neyret, S.; Vincent, B. The properties of polyampholyte microgel particles prepared by microemulsion polymerization. Polymer 1997, 38, 6129-6134. [CrossRef]

114. Braun, O.; Selb, J.; Candau, F. Synthesis in microemulsion and characterization of stimuli-responsive polyelectrolytes and polyampholytes based on N-isopropylacrylamide. Polymer 2001, 42, 8499-8510. [CrossRef]

115. Dowding, P.J.; Vincent, B.; Williams, E. Preparation and swelling properties of poly(NIPAM) "minigel" particles prepared by inverse suspension polymerization. J. Colloid Interface Sci. 2000, 221, 268-272. [CrossRef] [PubMed]

116. HernandezBarajas, J.; Hunkeler, D. Heterophase water-in-oil polymerization of acrylamide by a hybrid inverse-emulsion/inverse-microemulsion process. Polymer 1997, 38, 5623-5641. [CrossRef]

117. Landfester, K.; Willert, M.; Antonietti, M. Preparation of polymer particles in nonaqueous direct and inverse miniemulsions. Macromolecules 2000, 33, 2370-2376. [CrossRef]

118. Ming, W.H.; Zhao, Y.Q.; Cui, J.; Fu, S.K.; Jones, F.N. Formation of irreversible nearly transparent physical polymeric hydrogels during a modified microemulsion polymerization. Macromolecules 1999, 32, 528-530. [CrossRef]

119. Platkowski, K.; Pross, A.; Reichert, K.H. The inverse emulsion polymerization of acrylamide with pentaerythritolmyristate as emulsifier. 2. Mathematical modelling. Polym. Int. 1998, 45, 229-238. [CrossRef]

120. Pross, A.; Platkowski, K.; Reichert, K.H. The inverse emulsion polymerization of acrylamide with pentaerythritolmyristate as emulsifier-1. Experimental studies. Polym. Int. 1998, 45, 22-26. [CrossRef]

121. Wu, C.; Zhou, S.Q. Light scattering study of spherical poly(N-isopropylacrylamide) microgels. J. Macromol. Sci. Phys. 1997, 36, 345-355. [CrossRef]

122. Glukhikh, V.; Graillat, C.; Pichot, C. Inverse Emulsion Polymerization of acrylamide. 2. Synthesis and characterization of copolymers with methacrylic-acid. J. Polym. Sci. Pol. Chem. 1987, 25, 1127-1161. [CrossRef]

123. Sayil, C.; Okay, O.J. Swelling-shrinking hysteresis of poly(N-isopropylacrylamide) gels in sodium dodecylbenzenesulfonate solutions. Appl. Polym. Sci. 2002, 83, 1228-1232. [CrossRef]

124. Woodward, N.C.; Chowdhry, B.Z.; Leharne, S.A.; Snowden, M.J. The interaction of sodium dodecyl sulphate with colloidal microgel particles. Eur. Polym. J. 2000, 36, 1355-1364. [CrossRef]

125. Gilanyi, T.; Varga, I.; Meszaros, R.; Filipcsei, G.; Zrinyi, M. Interaction of monodisperse poly(N-isopropylacrylamide) microgel particles with sodium dodecyl sulfate in aqueous solution. Langmuir 2001, 17, 4764-4769. [CrossRef] 
126. Martin, B.D.; Ampofo, S.A.; Linhardt, R.J.; Dordick, J.S. Biocatalytic synthesis of sugar-containing poly(acrylate)-based hydrogels. Macromolecules 1992, 25, 7081-7085. [CrossRef]

127. Aggeli, A.; Bell, M.; Boden, N.; Keen, J.N.; Knowles, P.F.; McLeish, T.C.; Pitkeathly, M.; Radford, S.E. Responsive gels formed by the spontaneous self-assembly of peptides into polymeric beta-sheet tapes. Nature 1997, 386, 259-262. [CrossRef]

128. Jones, C.D.; Lyon, L.A. Dependence of shell thickness on core compression in acrylic acid modified poly(N-isopropylacrylamide) core/shell microgels. Langmuir 2003, 19, 4544-4547. [CrossRef]

129. Ghandehari, H.; Kopeckova, P.; Yeh, P.Y.; Kopecek, J. Biodegradable and pH sensitive hydrogels: Synthesis by a polymer-polymer reaction. Macromol. Chem. Phys. 1996, 197, 965-980. [CrossRef]

130. Jeong, S.H.; Huh, K.M.; Park, K. Hydrogel drug delivery systems. In Polymers in Drug Delivery; Ijeoma, F.U., Andreas, G.S., Eds.; Taylor \& Francis: Boca Raton, FL, USA, 2006; Volume 5, pp. 49-62. [CrossRef]

131. Boulmedais, F.; Tang, C.S.; Keller, B.; Voros, J. Controlled electrodissolution of polyelectrolyte multilayers: A platform technology towards the surface-initiated delivery of drugs. Adv. Funct. Mater. 2006, 16, 63-70. [CrossRef]

132. Grayson, A.C.R.; Choi, I.S.; Tyler, B.M.; Wang, P.P.; Brem, H.; Cima, M.J.; Langer, R. Multi-pulse drug delivery from a resorbable polymeric microchip device. Nat. Mater. 2003, 2, 767-772. [CrossRef] [PubMed]

133. Kawaguchi, H. Functional polymer microspheres. Prog. Polym. Sci. 2000, 25, 1171-1210. [CrossRef]

134. Pelton, R.; Richardson, R.; Cosgrove, T.; Ivkov, R. The effects of temperature and methanol concentration on the properties of poly(N-isopropylacrylamide) at the air/solution interface. Langmuir 2001, 17, 5118-5120. [CrossRef]

135. Lee, S.-K.; Park, Y.; Kim, J. Thermoresponsive behavior of magnetic nanoparticle complexed pNIPAm-co-AAc microgels. Appl. Sci. Basel 2018, 8, 1984. [CrossRef]

136. Debord, J.D.; Lyon, L.A. Thermoresponsive photonic crystals. J. Phys. Chem. B 2000, 104, 6327-6331. [CrossRef]

137. Debord, S.B.; Lyon, L.A. Influence of particle volume fraction on packing in responsive hydrogel colloidal crystals. J. Phys. Chem. B 2003, 107, 2927-2932. [CrossRef]

138. Lyon, L.A.; Debord, J.D.; Debord, S.B.; Jones, C.D.; McGrath, J.G.; Serpe, M.J. Microgel colloidal crystals. J. Phys. Chem. B 2004, 108, 19099-19108. [CrossRef]

139. Plunkett, K.N.; Berkowski, K.L.; Moore, J.S. Chymotrypsin responsive hydrogel: Application of a disulfide exchange protocol for the preparation of methacrylamide containing peptides. Biomacromolecules 2005, 6, 632-637. [CrossRef]

140. Kim, S.; Chung, E.H.; Gilbert, M.; Healy, K.E. Synthetic MMP-13 degradable ECMs based on poly(N-isopropylacrylamide-co-acrylic acid) semi-interpenetrating polymer networks. I. Degradation and cell migration. J. Biomed. Mater. Res. Part A 2005, 75, 73-88. [CrossRef]

141. Kim, S.; Healy, K.E. Synthesis and characterization of injectable poly(N-isopropylacrylamide-co-acrylic acid) hydrogels with proteolytically degradable cross-links. Biomacromolecules 2003, 4, 1214-1223. [CrossRef]

142. Nolan, C.M.; Reyes, C.D.; Debord, J.D.; Garcia, A.J.; Lyon, L.A. Phase transition behavior, protein adsorption, and cell adhesion resistance of poly(ethylene glycol) crosslinked microgel particles. Biomacromolecules 2005, 6, 2032-2039. [CrossRef] [PubMed]

143. Miyata, T.; Asami, N.; Uragami, T. Preparation of an antigen-sensitive hydrogel using antigen-antibody bindings. Macromolecules 1999, 32, 2082-2084. [CrossRef]

144. Yang, H.M.; Teoh, J.Y.; Yim, G.H.; Park, Y.; Kim, Y.G.; Kim, J.; Yoo, D. Label-free analysis of multivalent protein binding using bioresponsive nanogels and surface plasmon resonance (SPR). ACS Appl. Mater. Interfaces 2020, 12, 5413-5419. [CrossRef] [PubMed]

(C) 2020 by the authors. Licensee MDPI, Basel, Switzerland. This article is an open access article distributed under the terms and conditions of the Creative Commons Attribution (CC BY) license (http://creativecommons.org/licenses/by/4.0/). 